\title{
УГЛЕВОДОРОДЫ И КИСЛОРОДНЫЕ СОЕДИНЕНИЯ В БИТУМОИДЕ СЛАНЦА-КУКЕРСИТА
}

Настоящее исследование является продолжением работы ['], где были охарактеризованы промышленные пачки кукерсита по окислительной деструкции керогена. До окисления проба сланца обрабатывалась $3 \%$-ной соляной кислотой и экстракцией (спирт-бензол $1: 1$ ), выделялся битумоид, который затем подвергался анализу. Результаты данного анализа излагаются в настоящем исследовании.

Одна из характерных особенностей кукерсита - низкое содержание битумоида, что противоречит его древнему возрасту. Уже появилось несколько работ, в которых охарактеризованы углеводороды битумоида кукерсита. Показано, что $\boldsymbol{H}$-алканы битумоида содержат преимущественно 19-24 атома углерода $\left[{ }^{2}\right]$, при этом углеродные цепи в битумоиде более длинные, чем в структуре керогена; предполагается также высокое содержание бензпирена в битумоиде [ $\left.{ }^{3}\right]$.

Низкая концентрация битумоида в керогене и его групповой состав дают основание думать, что данный битумоид сингенетичен. Структура керогена кукерсита относительно хорошо известна, установлена сохранность в ней фрагментов исходного биологического вещества. Мы задались целью исследовать, как структурно связаны между собой битумоид и кероген. Одновременно анализировались четыре промышленные пачки кукерсита $-A, B, D$ и $E$ (снизу вверх). Анализу подвергался также асфальтит - богатый органическим веществом (OB) и битумоидом тонкий темноокрашенный слой, лежащий над слоем $B$.

Таблица 1

Характеристика битумоидов отдельных слоев

\begin{tabular}{|c|c|c|c|c|c|c|c|c|c|c|c|}
\hline \multirow[b]{2}{*}{ Слой } & \multirow[b]{2}{*}{ 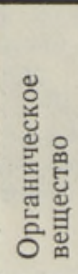 } & \multirow[b]{2}{*}{ 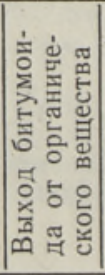 } & \multicolumn{4}{|c|}{ Элементный состав, \% } & \multicolumn{5}{|c|}{ Групповой состав, \% } \\
\hline & & & $\mathrm{C}$ & $\mathrm{H}$ & $\mathrm{N}$ & $\mathrm{H} / \mathrm{C}$ & $\begin{array}{l}\text { Пара- } \\
\text { фины }\end{array}$ & \begin{tabular}{|} 
Аро- \\
мати- \\
ческие \\
соеди- \\
нения
\end{tabular} & $\begin{array}{c}\text { Нейт- } \\
\text { раль- } \\
\text { ные } \\
\text { кисло- } \\
\text { родные } \\
\text { соеди- } \\
\text { нения }\end{array}$ & $\begin{array}{l}\text { Кис- } \\
\text { лоты }\end{array}$ & $\begin{array}{l}\text { Ас- } \\
\text { фаль- } \\
\text { тены }\end{array}$ \\
\hline $\begin{array}{l}E \\
D \\
\text { Асффальтит }\end{array}$ & $\begin{array}{l}30,9 \\
25,0\end{array}$ & $\begin{array}{l}0,72 \\
0,70\end{array}$ & $\begin{array}{l}65,7 \\
74,6\end{array}$ & $\begin{array}{l}10,2 \\
10,5\end{array}$ & $\begin{array}{l}0,5 \\
0,4\end{array}$ & $\begin{array}{l}1,86 \\
1,69\end{array}$ & $\begin{array}{l}5,9 \\
7,0\end{array}$ & $\begin{array}{l}6,6 \\
7,4\end{array}$ & $\begin{array}{l}30,5 \\
30,0\end{array}$ & $\begin{array}{l}26,3 \\
29,1\end{array}$ & $\begin{array}{l}30,5 \\
26,4\end{array}$ \\
\hline${ }_{B}{ }^{\text {слоя } B}$ & $\begin{array}{l}94,4 \\
47,6 \\
46,4\end{array}$ & $\begin{array}{l}8,20 \\
0,70 \\
0,71\end{array}$ & $\begin{array}{l}85,2 \\
78,2 \\
68,8\end{array}$ & $\begin{array}{l}10,1 \\
10,6 \\
10,7\end{array}$ & $\begin{array}{l}1,2 \\
0,5 \\
0,6\end{array}$ & $\begin{array}{l}1,42 \\
1,63 \\
1,85\end{array}$ & $\begin{array}{r}15,9 \\
7,1 \\
5,7\end{array}$ & $\begin{array}{r}37,4 \\
8,3 \\
6,0\end{array}$ & $\begin{array}{l}13,5 \\
28,8 \\
21,2\end{array}$ & $\begin{array}{l}23,8 \\
32,2 \\
29,3\end{array}$ & $\begin{array}{r}6,4 \\
23,6 \\
27,8\end{array}$ \\
\hline
\end{tabular}


Прибавлением петролейного эфира из битумоидов осаждались асфальтены, затем омылением спиртовой щелочью из них выделялись кислоты. Нейтральный битумоид разделялся препаративной тонкослойной хроматографией на группы соединений [ $\left.{ }^{4}\right]$. Индивидуальный состав групп определялся газохроматографически на аппарате Хром-4 с использованием колонок различной полярности. Выход, групповой и элементный составы битумонда представлены в табл. 1.

Содержание ОВ в отдельных слоях колеблется в широких пределах, но выход битумоида из них одинаков - $0,70-0,72 \%$. Главные компоненты в битумоиде - различные кислородные соединения. Содержание углеводородов низкое $(12-15 \%)$, половину из них составляют парафины. Групповые составы по слоям также близки. Однако совсем другую характеристику имеет асфальтит: содержание минерального вещества в нем низкое, в его ОВ много углерода и мало кислорода. Половину битумоида, выделенного из асфальтита, составляют углеводороды, примечательно высокое содержание ароматических соединений и низкое асфальтенов. Асфальтит и его битумоид коренным образом отличаются от составляющих кукерсита, поэтому, как представляется, они должны иметь иное происхождение и иной путь фоссилизации. Перейдем к обсуждению состава отдельных групп соединений.

Парафины, как обычно в подобных продуктах, представлены в основном нормальными соединениями $\mathrm{C}_{13}-\mathrm{C}_{34}$ (рис. 1). Высокую концентрацию имеют $\mathrm{C}_{19}-\mathrm{C}_{24}$, в этом пределе коэффициент нечетности $(\mathrm{KH})$ наиболее высок. КН показывает соотношение концентраций $\boldsymbol{H}$-парафинов с нечетным и четным числом атомов углерода; высокие значения КН указывают на непосредственное происхождение парафинов из высших растений, низкие - из продуктов бактериальной деятельности или геохимических процессов деградации. В табл. 2 даны КН для парафинов до $\mathrm{C}_{24}$ и выше. Основная часть парафинов имеет среднее значение КН $(1,2-1,5)$, у длинноцепочечных оно приближается к единице. Парафины с максимумом у $\mathrm{C}_{23}$ и низким $\mathrm{KH}$ часто встречаются в горючих сланцах; предполагается, что они бактериального происхождения. Подобные бактериальные парафины установлены в почвенных липоидах [5], здесь их КН еще ниже. Судя по концентрационному распределению и различию в КН, длинно- и короткоцепочечные парафины имеют разные пути образования.

Таблица 2

Некоторые характеристики парафинов отдельных слоев

\begin{tabular}{|c|c|c|c|c|}
\hline \multirow{2}{*}{ Слой } & \multicolumn{2}{|c|}{ Коэффициент нечетности } & \multirow{2}{*}{$\frac{i \mathrm{C}_{19}}{i \mathrm{C}_{20}}$} & \multirow{2}{*}{$\frac{i \mathrm{C}_{19}+i \mathrm{C}_{20}}{H-\mathrm{C}_{17}+H-\mathrm{C}_{18}}$} \\
\hline & $\mathrm{C}_{17}-\mathrm{C}_{23}$ & $\mathrm{C}_{25}-\mathrm{C}_{31}$ & & \\
\hline$E$ & 1,28 & 0,96 & 1,64 & 0,31 \\
\hline$D$ & 1,26 & 1,09 & 1,53 & 0,36 \\
\hline$\underset{B}{\text { Асфальтит }}$ & 1,20 & 1,17 & $\overline{74}$ & $\overline{64}$ \\
\hline$A$ & $\begin{array}{l}1,48 \\
1,58\end{array}$ & $\begin{array}{l}1,13 \\
1,12\end{array}$ & $\begin{array}{l}1,74 \\
1,10\end{array}$ & $\begin{array}{l}0,64 \\
0,38\end{array}$ \\
\hline
\end{tabular}

Из парафинов присутствует небольшое количество ациклических изопреновых углеводородов, главные представители - пристан $\left(i \mathrm{C}_{19}\right)$ и фитан $\left(i \mathrm{C}_{20}\right)$ (табл. 2). По сравнению с близкокипящими $\mu$-парафинами $\mathrm{C}_{17}$ и $\mathrm{C}_{18}$, концентрация $i \mathrm{C}_{19}$ и $i \mathrm{C}_{20}$ низкая (это редкое явление в горючих сланцах) и их соотношение другое, чем обычно в горючих сланцах 


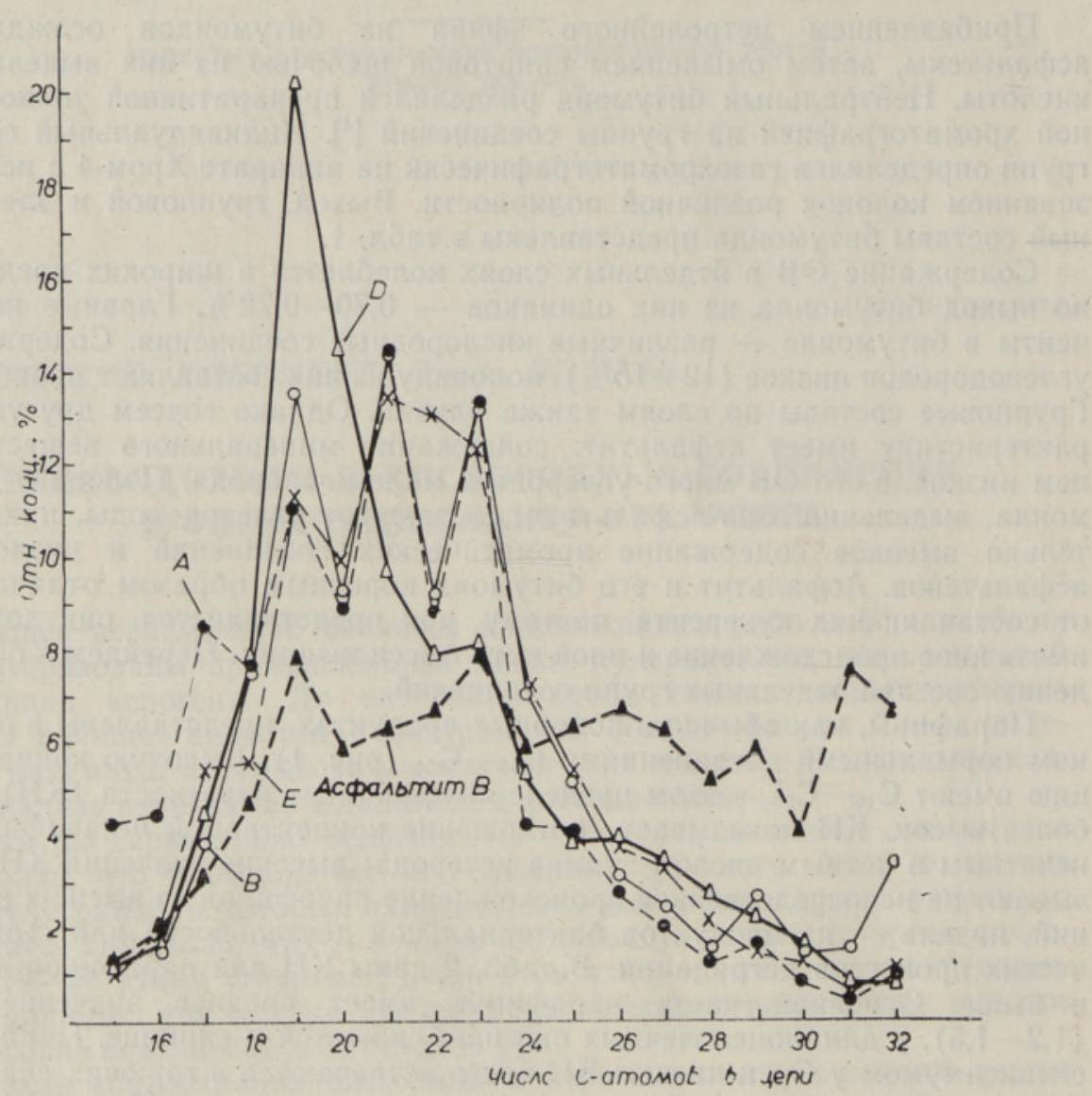

Рис. 1. Состав $H$-парафинов, выделенных из слоев кукерсита $A, B, D$ и $E$ и асфальтита $B$.

(чаще всего превалирует фитан). Указанное различие, возможно, обусловлено особыми (аллохтонными) условиями образования кукерсита и присутствием кислорода при его седиментации [6].

В насыщенных группах битумоидов установлено также наличие циклических изопреноидов - стеранов и тритерпанов, количество которых значительно в слое $B$. Их количество больше ожидаемого в таком древнем керогене, который образовался только из водорослей.

В общих чертах составы углеводородов в отдельных слоях близки. Очень отличается только состав $\boldsymbol{H}$-парафинов асфальтита (рис. 1): здесь значительно больше парафинов с длинной цепью и КН ниже. При хроматографировании парафины дают высокий «горб», что указывает на наличие множества неразделенных соединений.

Ароматические структуры топливу сапропелитового типа несвойственны. Небольшие группы битумоидов по их адсорбционным свойствам соответствуют ароматическим углеводородам. Часть из них летуча и состояла из множества соединений, которые тщательно не анализировались. По температуре кипения они соответствуют трехъядерным соединениям.

Самая интересная группа - нейтральные кислородные соединения. Hе всегда в битумоидах присутствуют алифатические кетоны, в нашем 

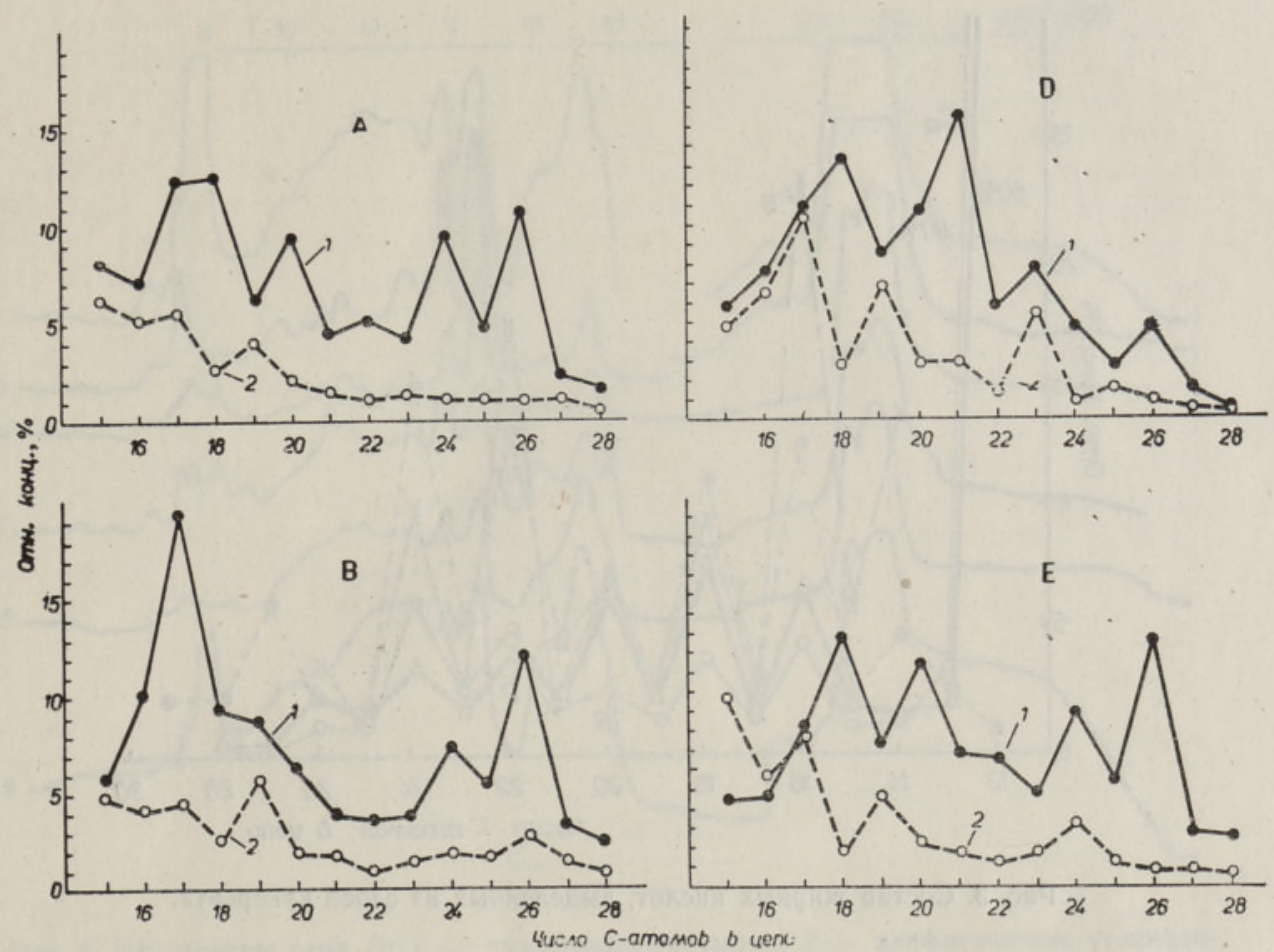

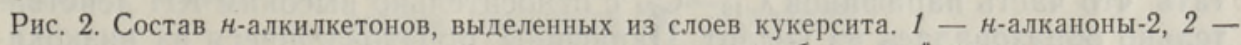
кетоны с центральным расположением карбонильной группы.

случае они также имели особый состав (рис. 2). По положению карбонильной группы в цепи кетоны разделяются на две структурные группы: большинство из них являются $\boldsymbol{H}$-2-алканонами, у остальных карбонильная группа располагается в центре цепи или близко к ней. Кетоны, образующиеся в результате биосинтеза, имеют высокий КН [7], повышенный КН наблюдается также у кетонов, выделяемых из геолипоидов. В случае кетонов кукерсита, наоборот, повышенную концентрацию имеют кетоны с четным числом атомов углерода (рис. 2), особенно отчетливо это выражено у метилкетонов. У кетона $\mathrm{C}_{22}$ наблюдается концентрационный минимум, который разделяет кетоны на две части.

Предполагается, что $H$-парафины и кетоны в био- и геолипоидах образуются одинаковым путем - при декарбоксилировании $\beta$-кетокислот [ $\left.{ }^{7}\right]$. Преобладание парафинов с четным числом углеродных атомов наблюдается в природе редко $\left.{ }^{8}\right]$, и механизм их образования не вполне выяснен. Еще труднее объяснить генезис соответствующих кетонов.

Кислоты, выделенные из битумоидов, разделялись в виде метиловых эфиров препаративной тонкослойной хроматографией в зависимости от содержания в них функциональных групп. Содержание одноосновных (жирных) кислот - $18-28 \%$. Остальные кислоты адсорбировались сильнее и газохроматографическому анализу не подвергались. Состав жирных кислот по слоям представлен на рис. 3. Обычно в геолипоидах главные кислоты - это $\mathrm{C}_{16}$ и $\mathrm{C}_{18}$. Нами наблюдался еще один концентрационный максимум - при $\mathrm{C}_{22}$ и $\mathrm{C}_{24}$. Признаки биологического происхождения у кислот сохранились лучше, чем у парафинов: «четность» кислот выше, чем «нечетность» парафинов. Следовательно, можно счи- 


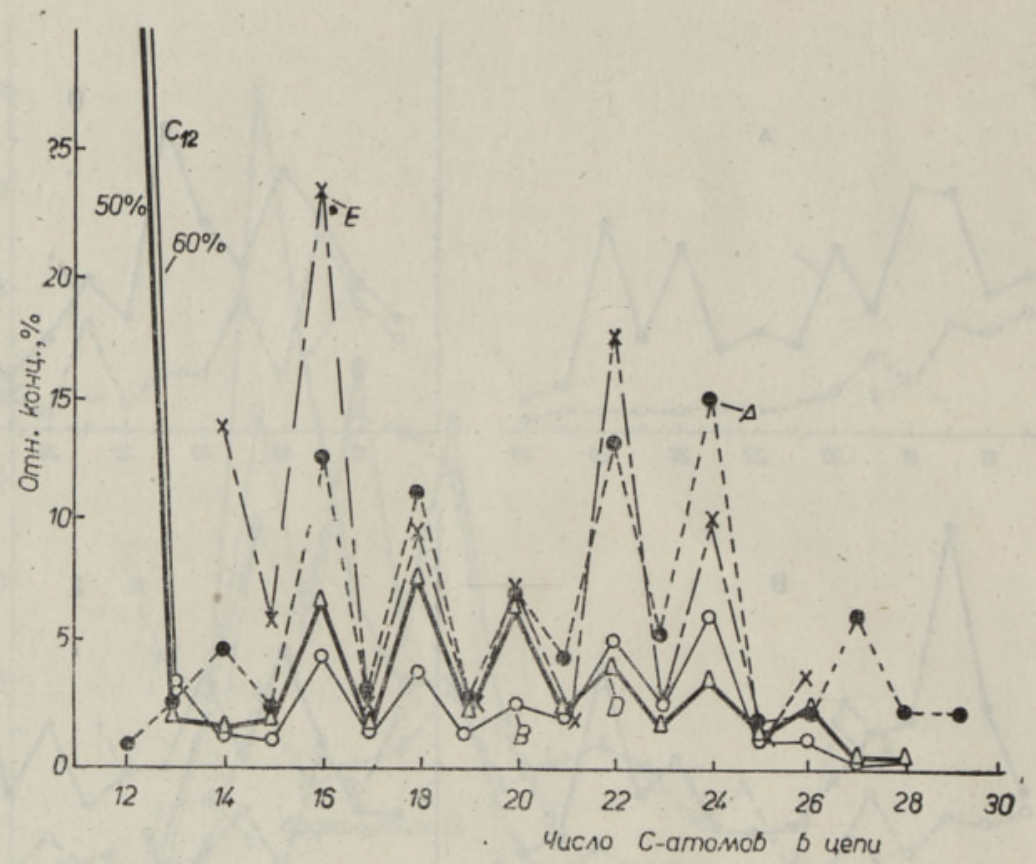

Рис. 3. Состав жирных кислот, выделенных из слоев кукерсита.

тать, что часть парафинов $\mathrm{C}_{19}-\mathrm{C}_{24}$ с относительно высоким $\mathrm{KH}$ действительно образовалась из кислот. Парафины, образовавшиеся из низкокипящей части кислот, вследствие их высокой подвижности могли эмигрировать, что вполне возможно тогда, когда парафинообразование происходило на первых этапах литификации.

Генетически связаны, очевидно, также кетоны и жирные кислоты обе группы имеют бимодальное распределение, концентрационный минимум кислот находится при $\mathrm{C}_{20}$, кетонов - при $\mathrm{C}_{22}$. Кривые распределения обоих групп в целом близки, если только не учитывать, что кетоны содержат на два атома углерода больше, чем кислоты. Их генетическая связь объяснима двояко. 1) Кетоны (алканоны-3) образуются из кислот кетонной конденсацией с пропионовой кислотой. Эта реакция бимолекулярная и требует большого избытка пропионовой кислоты, поэтому ее протекание, исходя из геологических условий, вряд ли возможно. 2) Кислоты образуются из кетонов (алканонов-2) путем окислительного расщепления второй связи рядом с карбонильной группой. Однако этим объяснениям противоречит то, что «четность» кислот выше, чем кетонов. Таким образом, вопрос о генетической связи между кетонами и кислотами остается пока открытым.

Структура асфальтенов исследовалась при пиролизе в стеклянной трубке, которую нагревали на пламени горелки. Составы пиролизатов из асфальтенов $A, B, D, E$ оказались близкими. В жидком пиролизате было много $\boldsymbol{H}$-парафинов $\mathrm{C}_{10}-\mathrm{C}_{33}$, концентрационный максимум лежал в пределах $\mathrm{C}_{23}-\mathrm{C}_{28}, \mathrm{KH} \approx 1$. На хроматограммах присутствовали также пики множества соединений, кипящих в пределах $250-350^{\circ} \mathrm{C}$, которые идентифицированы не были. Таким образом, в структуре асфальтенов присутствуют $\boldsymbol{H}$-алкановые цепи, но их состав отличается от состава парафинов битумоида.

Следует учесть, что основная часть битумоида не летуча и газовая 


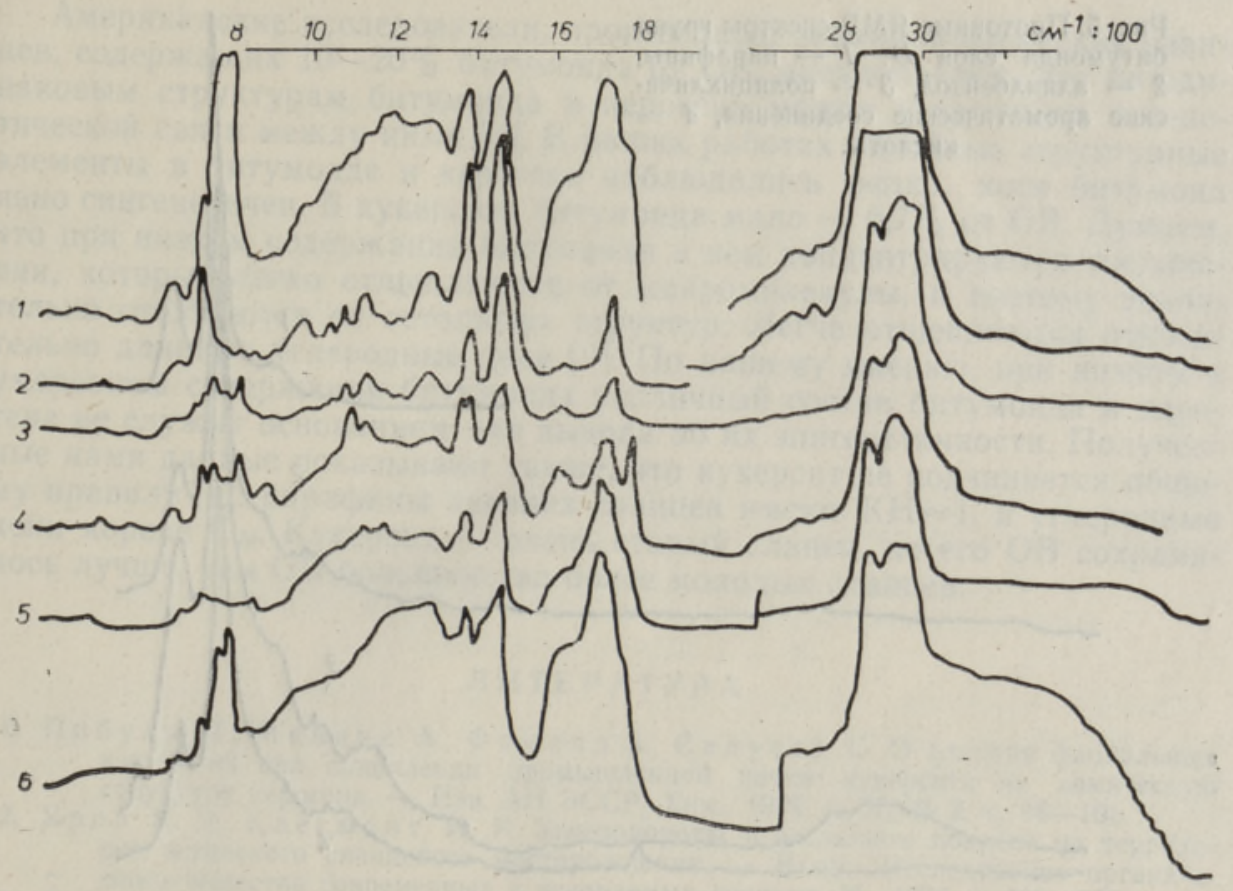

Рис. 4. ИК-спектры слоя $D: 1$ - суммарный битумоид, 2 - алифатические углеводороды, 3 - алкилбензолы, 4 - полициклические ароматические соединения, 5 - кислородные соединения, 6 - кислоты.

хроматография ее состава не отражает. Некоторые данные о составе высокомолекулярной части можно получить при применении спектральных методов.

Для битумоидов и их фракций были сняты ИК-спектры (аппарат UR-10, в таблетках $\mathrm{KBr}$ ) (рис. 4). В общих чертах спектры соответствующих фракций всех слоев сходны. Значительно отличаются по спектрам между собой фракции каждого отдельного слоя. Максимум поглощения при $720 \mathrm{~cm}^{-1}$ указывает на присутствие длинных углеродных цепей в фракциях углеводородов, обилие $\mathrm{CH}_{2}$ - и $\mathrm{CH}_{3}$-групп подтверждают максимумы при 1455 и $1385 \mathrm{~cm}^{-1}$. В структуре кислородных соединений много карбонильных и карбоксильных групп $\left(1640-1720 \mathrm{~cm}^{-1}\right)$, небольшое их количество находится также в ароматических фракциях. Спиртовой гидроксил отсутствует.

Распределение водорода по отдельным структурным элементам исследовалось ЯМР-спектроскопией (аппарат KРZ-2) (рис. 5). ЯМР-спектры подтверждают наличие длинных углеродных цепей в алифатических фракциях (химические сдвиги при 0,9 и 1,3 м. д.). В ароматических фракциях также много алифатических структур, содержание ароматического водорода $(7$ м. д.) составляет в этих фракциях лишь небольшую долю от суммарного водорода.

Особо следует остановиться на асфальтите, лежащем на слое $B$. Как было уже отмечено, он и его битумоид ничего общего с ОВ кукерсита не имеют и в нем мало летучих парафинов. Вопреки ожидаемому, при пиролизе асфальтенов его битумонда образовалось довольно много $H$-парафинов $\mathrm{C}_{10}-\mathrm{C}_{33}$, в основном $\mathrm{C}_{14}-\mathrm{C}_{26}$. Особенно интересно образование большого количества изопреноида $i \mathrm{C}_{19}$, концентрация которого превы- 
Рис. 5. Протонные ЯМР-спектры групп битумоида слоя $D: 1$ - парафины, 2 - алкилбензол, 3 - полициклические ароматические соединения, 4 кислоты.

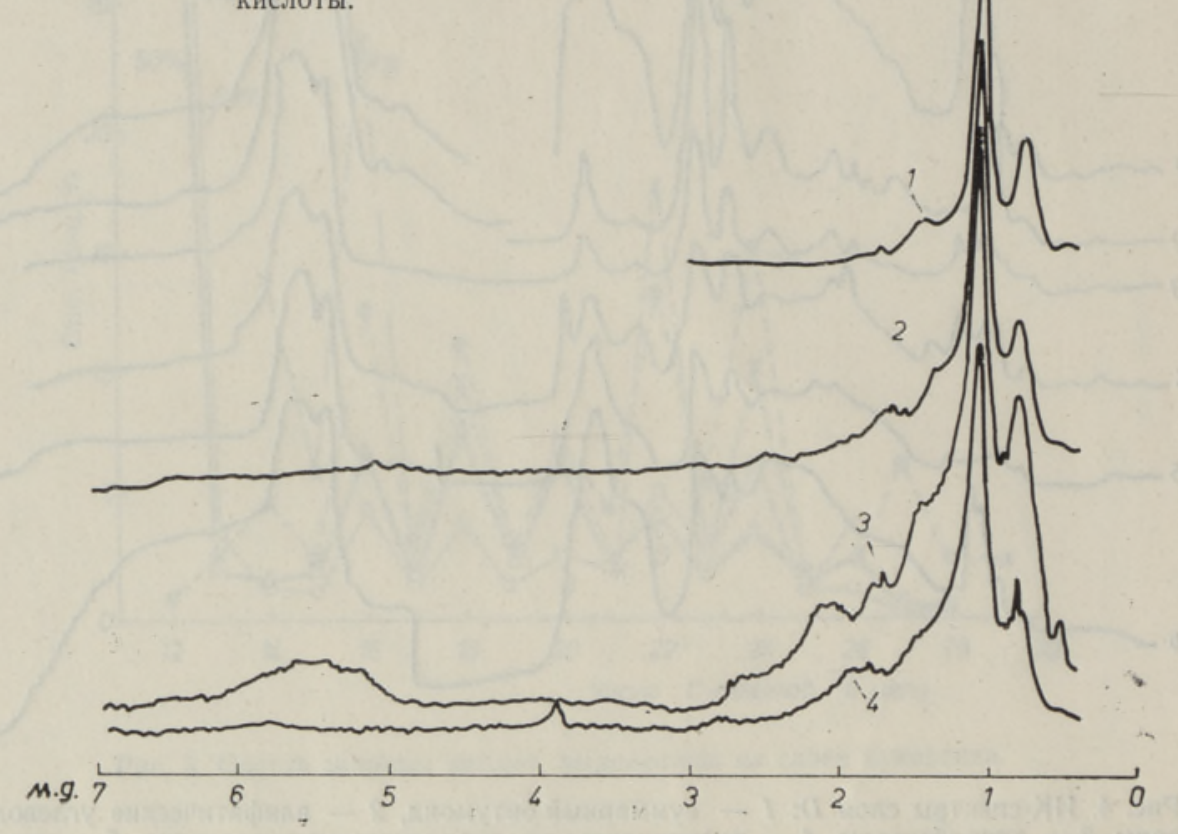

шала концентрацию близкокипящего $\mathrm{H}$ - $\mathrm{C}_{17}$; количество $i \mathrm{C}_{20}$ было в несколько раз меньше. По элементному составу и другим данным, асфальтит слоя $B$ идентичен с конкрециями асфальтита, иногда встречаемыми в отложениях нижнего палеозоя Северной Эстонии []. По общему мнению, асфальтит является привнесенным извне веществом, - возможно, полимеризованной нефтью. Асфальтит - высокопревращенное вещество, единственными биологическими «метками» его исходного вещества служат изопреновые углеводороды, образующиеся при пиролизе. Так как OB асфальтита содержит много водорода и растворимых веществ, оно является продуктом не окисления или катагенеза, а, видимо, жизнедеятельности бактерий.

Отдельные группы, входящие в состав битумоида, генетически восходят к нескольким источникам: например, парафины - частично бактериального происхождения, а частично источником их образования были высокоорганизованные организмы. Формирование кетонов и жирных кислот, судя по наличию при них двух концентрационных максимумов, также шло двумя путями. Структурная связь между отдельными группами проявляется слабо. Очень интересный состав имеют кетоны с преобладанием «четных» гомологов. Указанное явление нами установлено впервые, и пока мы не можем его объяснить.

В составе битумоидов отдельных слоев имеются небольшие различия, но в общих чертах они похожи, как и нерастворимое ОВ разных слоев. По постоянству состава, низкому содержанию углеводородов и высокому гетеросоединений мы вынуждены считать битумоид сингенетичным с керогеном. При этом хорошо известно, что структуры, установленные в битумоиде, в керогене отсутствуют: $H$-углеводородные структуры в керогене содержат не более 17 углеродных атомов [ $\left.{ }^{2}\right]$. 
Американские исследователи, произведшие анализ колорадских сланцев, содержащих 10-20\% битумоида от ОВ, предполагают, что по одинаковым структурам битумоида и керогена можно утверждать о генетической связи между ними [10]. В наших работах подобные структурные элементы в битумоиде и керогене наблюдались редко, хотя битумоид явно сингенетичен. В кукерсите битумоида мало - $0,7 \%$ от ОВ. Думаем, что при низком содержании битумоида в нем концентрируются соединения, которые легко отщепляются от макромолекулы, и поэтому значительно отличаются от остальных структур. Легче отщепляются относительно длинные углеродные цепи [11]. По нашему мнению, при низком и умеренном содержании битумоида различный состав битумоида и керогена не служит основанием для вывода об их эпигенетичности. Полученные нами данные показывают также, что кукерсит не подчиняется общему правилу $\left[{ }^{12}\right]$ : парафины древних сланцев имеют $\mathrm{KH} \approx 1$, и углеродные цепи короче $\mathrm{C}_{22}$. Кукерсит - очень старый сланец, но его ОВ сохранилось лучше, чем ОВ большинства более молодых сланцев.

\section{ЛИТЕ РА Т У РА}

1. Побуль Л., Мянник А., Фомина А., Салусте С. О влиянии фациальных изменений при накоплении промышленной пачки кукерсита на химическую структуру керогена. - Изв. АН ЭССР. Хим., 1978, т. 27, № 2, с. 96-101.

2. У ров К. Э., Клесмент И. Р. Углеводороды в осадочном покрове на территории эстонского сланцевого месторождения. - В кн.: Исследование органического вещества современных и ископаемых осадков. М., 1976, с. 292-298.

3. Л аус Т., Паальме Л., Эленурм А., Губергриц М. Генетически связанный с керогеном 3,4-бензпирен в продуктах термического разложения сланцакукерсита. - Изв. АН ЭССР. Хим. Геол., 1975, т. 24, № 1, с. 30-36.

4. K l esment, I. Application of chromatographic methods in biogeochemical investigations. - J. Chromatogr., 1974, v. 91, p. 705-713.

5. Клесмент И., Л иллеп Н. К геохимии почвенных углеводородов Северной Эстонии. - Изв. АН ЭССР. Хим., 1978, т. 27, № 1, с. 8-14.

6. Клесмент И. Р. Геохимическая история изопреноидов и порфиринов в седиментах. - В кн.: Тезисы докладов Всесоюзной конференции по химии и геохимии порфиринов. Душанбе, 1977 , с. 57.

7. Egl int o n, O., H a m ilt o n, R. Leaf epicuticular waxes. - Science, 1967, v. 156, N 3780 , p. $1322-1335$.

8. Dembicki, H., Meinschein, W. G., Hattin, D. E. Possible ecological and environmental significance of the predominance of even carbon number $C_{20}-C_{30}$ alkanes. - Geochim. Cosmochim. Acta, 1976, v. 40, p. 203-208.

9. Люткевич Е. М., Кур ба тская А. И. О генезисе асфальтитовых «лепешек», или галек, из нижнего кембрия и нижнего и среднего ордовика Прибалтики. Тр. Всес. н.-и. геол.-развед. нефт. ин-т, 1964, вып. 227, с. 101-111.

10. S e if e rt, W. K. Steranes and terpanes in kerogen pyrolysis for correlation of oils and source rocks. - Geochim. Cosmochim. Acta, 1978, v. 42, p. 473-484.

11. К ле см ен т И. Р. Алифатические структуры в керогене горючих сланцев. - В кн.: Исследование органического вещества современных и ископаемых осадков. М., 1976 , c. $187-195$.

12. Гуляева Н. Д., Арефьев О. А., Петров Ал. А. Закономерности распределения нормальных и изопренондных алканов в горючих сланцах. - Химия тв. топлива, 1977, № 6, с. 25-31.

Ннститут химии

Академии наук Эстонской ССР
Поступила в редакцию 27/X 1978 
Ruth PAIS, I. KLESMENT, Linda POBUL

\section{KUKERSIIDI BITUMOIDI SUSIVESINIKUD \\ JA HAPNIKUUHENDID}

Bitumoidi n-parafiinid on bakteriaalset päritolu, isoprenoide on vähe. Alküülketoonid sisaldavad enamasti paarisarvu süsinikuaatomeid, on vôimalik geneetiline side bitumoidi rasvhapete ja ketoonide vahel. Kukersiidis leiduv asfaltiit on epigeneetiline. Bitumoid ja kerogeen ei sisalda süngeneetilisele moodustumisele vaatamata sarnaseid struktuurielemente.

Ruth PAIS, I. KLESMENT, Linda POBUL

\section{HYDROCARBONS AND OXYGEN COMPOUNDS IN THE BITUMEN OF OIL SHALE KUKERSITE}

$n$-Paraffins $\mathrm{C}_{19}-\mathrm{C}_{26}$ are of a bacterial origin, isoprene hydrocarbons have a low concentration. Alkylketones contain mostly even number of carbon atoms; a genetic relationship between ketones and fatty acids of bitumoid is possible. In spite of the syngenetic formation of kerogen and bitumen, they do not contain similar structural elements. 